\title{
TÜRKİYE'DE BÜYÜK VERİ İLE DEĞER YARATAN İŞLETMELER: ÖZEL SEKTÖR UYGULAMALARI ÜZERINE BİR İNCELEME
}

$* * *$

\author{
BUSINESSES CREATING VALUE WITH BIG DATA IN TURKEY: A \\ REVIEW ON PRIVATE SECTOR APPLICATIONS
}

\begin{abstract}
$\ddot{\mathbf{O} z}$
Küresel ölçekte verinin her geçen gün artmasıyla birlikte dijital dönüşümün yapı taşlarından biri olarak gündeme gelen Büyük Veri $(B V)$, iş dünyasının önemli bir bileşeni haline gelmiştir. Farkl yapılarda, hızlı ve büyük hacimde üretilen veriler olarak tanımlanabilen BV'de amaç, doğrulanabilir /güvenilir nitelikte verilerle değer yaratabilmektir. Türkiye'de BV, birçok araştırmacı ve işletme için yenidir. Kamu kurumlarında BV çalı̧̧maları ve uygulamaları bulunmaktayken özel sektörde çoğunlukla yatırımlar düzeyindedir. Bu nedenle hem teknik hem de işletme gereksinimlerinin araştırılması ve anlaşılması gerekmektedir. Bu çalışmada amaç, dijitalleşme sürecinde işletmelerin BV ile nasıl değer yaratabilecekleri ya da verilerden yola çıkarak karar süreçlerini nasıl daha verimli hale getirebilecekleri konusunda içgörüler sağlamak, araştırmacıların verimliliğini ve performansını artırmaya katkıda bulunabilecek kritik gelişmeler hakkında yol gösterici olmaktır. Çalışmada, işletmelerin çok fazla ve hızlı üretilen veriye sahip olmasına sebep olan veri kaynakları, iş yapma şekillerinin değişimi, elde edilen katma değere yönelik uygulamaları desteklemek üzere kaynak araştırması yapılarak, Türkiye'de özel sektörde BV'nin kullanımını açılklayan uygulamalar incelenmiştir. Farklı sektörlerden örnekler ele alınmış, ulaşılan uygulamalar dahilinde BV ile yaratılan değerler ve iş yapma şekillerinin değişimi ortaya konmuştur. Sonuçlar, BV ile işletmelerde maliyetleri düşürme, verimliliği artırma, yeni ürün/hizmet geliştirme, pazarlama stratejileri, müşteri kaybının önlenmesi ve karlılı yönleriyle büyük faydalar elde etmenin ve rekabette fark yaratmanın mümkün olduğunu göstermektedir.
\end{abstract}

Anahtar Kelimeler: Büyük Veri, Türkiye'de Büyük Veri, Issletmelerde Büyük Veri, Büyük Veri Örnekleri, Büyük Veri Uygulamalart.

\begin{abstract}
Big Data (BD), which has come to the fore as one of the building blocks of digital transformation with the increase of data on a global scale, has also become an important component of the business world. The purpose of $B V$, which can be defined as data produced in different structures, fast and in large volumes, is to create value with verifiable/reliable data. Therefore, it is necessary to research and understand both technical and operational requirements. BD in Turkey is new to many researchers and businesses. While there are BD studies and applications in public institutions, it is mostly at the level of investments in the private sector. The purpose of this study is to provide insights on how businesses can create value with $B D$ in the digitalization process or how they can make decision processes more efficient based on data, and provide guidance about critical developments that can contribute to increasing the productivity and performance of researchers. In the study, the data sources that cause the enterprises to have too much and rapidly produced data, the change in the way of doing business, the applications explaining the use of $B D$ in the private sector in Turkey by literature review in order to support the applications for the added value obtained were investigated. Examples from different sectors were examined, the values created with $B D$ and the change in the way of doing business within the scope of the applications reached were revealed. The results show that it is possible to make great benefits and make a difference in the competition with BD in terms of reducing costs, increasing productivity, developing new products/services, marketing strategies, prevention of customer loss, and profitability.
\end{abstract}

Keywords: Big Data, Big Data in Turkey, Big Data in Business, Big Data Examples, Big Data Applications.

\footnotetext{
* Dr. Öğr. Üyesi, İnönü Üniversitesi, İ̈BF, İşletme Bölümü, sebnem.yilmaz@inonu.edu.tr, Malatya, Türkiye, ORCID: 0000-0003-3730-2363
} 


\section{GİRIŞ}

Günümüzde, verinin katlanarak arttığı bilinmektedir. Veri miktarının artışındaki en büyük sebep; makineler, akıllı okuyucular, uydular, cep telefonları, bilgisayarlar gibi pek çok cihazdan üretilen verilerdir. İnternet ve sosyal medyanın yaygınlaşması ile insanların beğendikleri içerikleri bu ortamlarda paylaşma isteği de verinin artmasındaki diğer önemli sebeptir (Gobble, 2013:64; Su, 2017:3-4; Özdoğan, 2016:12-15). Sadece internet ortamı düşünüldüğünde, 2020 yılında bir dakikada internette neler yapıldığını gösteren bir araştırmadan bazı örnekler aşağıdaki gibidir (Lewis, 2020):

- Akıllı cihazlara 400.000 uygulama yüklenmektedir. Bunlardan biri olan mesaj uygulamaları ile 59 milyon ve telefon operatörleri üzerinden 19 milyon metin, fotoğraf, video, ses içeren mesaj; ayrıca e-posta sistemleriyle 190 milyon posta gönderilmekte ve alınmaktadır.

- Google arama motorunda 4.1 milyon sorgu gerçekleşmekte, e-ticaret sitelerinde 1.1 milyon dolarlık çevrim içi harcama yapılmaktadır.

- Netflix üzerinden 764.000 saat video izlenmekte, Youtube'da 4.7 milyon video görüntüleme gerçekleşmektedir. Sosyal medya uygulamalarından Instagram'da 694.444 metin ve fotoğraf kaydırma hareketi tanımlanmakta, Facebook'a 1.3 milyon giriş yapılmakta, Twitter'dan 194.444 kısa mesaj ve Tiktok’tan 1.400 kısa video paylaşılmaktadır.

2020 yılında ayrıca, 2019 yılı sonlarında başlayan COVID19 küresel salgının etkisi ile yaygınlaşan dijital servis kullanımı (video konferans, e-alışveriş, eve yemek teslimatı, 7/24 mobil para transferleri uygulamaları) da veri miktarını önemli ölçüde artırmıştır (Şener, 2020).

Yukardaki örnekler incelendiğinde, verinin sadece miktarının değil aktarım hızının ve yapısal çeşitliliğinin (metin, ses, sorgu, tıklama, video...) de önem arz ettiği görülmektedir. Bu doğrultuda "farklı yapılarda, hızlı ve büyük hacimde üretilen veriler" olarak tanımlanabilen Büyük Veri (BV) (Big Data(BD)) kavramı gündeme gelmektedir. Veriler, söz konusu bu "büyük"lük sebebiyle geleneksel veri tabanları yerine bulut (cloud), veri ambarları (datamarts) ve veri gölleri (datalakes) olarak adlandırılan sistemlerde depolanmakta; veri tabanı yönetim sistemleri yerine Yapay Zekâ (YZ) ve Veri Madenciliği (VM) yöntemleriyle analiz edilmektedir. $\mathrm{Bu}$ analizler sayesinde güvenilir/doğrulanabilir BV'den değer yaratmak mümkün olmaktadır. Verinin doğruluğunu olumsuz etkileyen faktörler ekonomiye katkı sunacak gerçek değerin elde edilmesini engellemektedir. BV işletme, finans-bankacılık, sağlık, ziraat, kamu ve eğitim gibi çok çeşitli alanlarda değer yaratmaktadır. Örneğin, iş dünyasında kişiselleştirilmiş ürün ve hizmet sunumuna dönük iş modelleri geliştirilebilmekteyken sağlıkta, akıllı cihazlarla toplanan verilerle hastalıkları öğrenebilen modeller oluşturulabilmekte; tarımda, sensörlerle toprağın, havanın, bitkilerin durumları tespit edilerek ürünler özel bir bakımla yetiştirilebilmektedir.

$\mathrm{BV}$, işletmelerin dijital dönüşümlerini sağlayan yeni dijital teknolojilerden biridir. Yeni dijital teknolojiler işletmeleri iyileştirmek için kullanılmakta, mevcut iş modelleri dijitalleşerek dönüşmekte ve yeni iş modelleri oluşmaktadır. Bunun sonucunda, işletmelerin iş değer zincirleri ve organizasyonları farklı yapılar gerektirmektedir. Ancak farklı dijital teknolojileri üretebilen, kullanabilen ya da farklı şekillerde pazarlayabilen işletmeler yeni ekonomik şartlara uyum sağlayabilecekler ve yeni zorlu rekabet ortamındaki dijital pazarda hayatta kalabileceklerdir (Klein, 2020:25).

Türkiye'de BV, birçok araştırmacı ve işletme için yenidir. Özel sektördeki BV uygulamaları artış göstermekle birlikte büyük bir kısmı bu konuya yapılan yatırımlar düzeyindedir. Buna karşılık kamu kurumlarında gerçekleştirilmiş başarılı BV uygulamaları ya da uygulamalara girdi sağlayabilecek projeler daha fazladır. Bunlara, Kamu Bilgi Yönetim Sistemi (KAYSİS), enerji tahmin sistemi, e-bildirge sistemi, Milli Eğitim Bakanlığı Bilişim Sistemleri (MEBBİS), e-okul, eNabız gibi çalışmalar örnek olarak verilebilir (BTK, 2020; Sağıroğlu, 2017:90). Ayrıca son iki yılda, Araç ve Sürücü Davranış Modellemesi, Erken Uyarı Sistemleri, Dolandırıcılık Tespiti, Canlı Trafik 
Tahmini uygulamaları (Sağıroğlu, 2019:52) ile BV kullanılmaya başlanmıştır. Ancak kamuda, özel sektörde ve akademik çevrede yapılan çalışmalar dünyada yapılanlara göre daha az sayıdadır. BV uygulamalarının ve çözüm ortaklarının sunduğu hizmetlerin artmasıyla birlikte konuya olan ilgi de artmaktadır. Konudaki en önemli gelişmelerden biri Sabancı Üniversitesi tarafından Massachusetts Institute of Technology (MIT) ve Akbank'ın stratejik ortaklığıyla kurulan Büyük Veri Davranış Analizi ve Görselleştirme Laboratuvarı'dır. Laboratuvar Türkiye'de sektörün ve işletmelerin BV ihtiyaçlarına cevap verebilecek akademi-iş ortaklığının örnek ilk girişimidir. Bu laboratuvarda çeşitli kaynaklardan toplanan BV'nin analiziyle insanların günlük yaşamdaki ve sosyal ortamlardaki davranışlarını açıklamak ve tahmin etmek için matematiksel modeller ve teknikler geliştirmek amaçlanmıştır (Sabancı Üniversitesi, 2021).

$\mathrm{Bu}$ çalışmanın amacı, işletmelerin BV ile nasıl değer yaratabilecekleri ya da verilerden yola çıkarak karar süreçlerini nasıl daha verimli hale getirebilecekleri konusunda içgörüler sağlamak, araştırmacıların verimliliğini ve performansını artırmaya katkıda bulunabilecek kritik gelişmeler hakkında yol gösterici olmaktır. Araştırma yöntemini BV kavramının bileşenleri ve işletme alanındaki uygulamalarına konu olan kaynak araştırması oluşturmaktadır. İncelenen kaynaklarda BV'nin işletmelerdeki kullanım alanları belirlenmiştir. Kullanım alanlarının kapsamlı araştırmasına dayanarak işletmelerde BV'nin hangi alanlarda nasıl değer yarattığı ortaya çıkarılmış daha sonra Türkiye'de özel sektörde BV uygulamalarında başarılı olmuş işletmelere yer verilmiştir. Bu işletmelerin BV kaynakları, BV'den elde ettikleri değerler ve BV'nin işletmelerin iş yapma şekillerini nasıl etkilediği ortaya konmuştur.

\section{LITERATÜR TARAMASI}

İşletmelerde BV kullanımına ilişkin literatür taramasında ulaşılan kaynaklardan biri olan Davenport ve Dyche (2013), büyük işletmelerin BV organizasyon yapısı ve bunun için gerekli beceriler hakkındaki düşüncelerini sektörden örneklerle açıklamışlar; BV teknolojilerinden Analytics 3.0 dönemini tanımlamışlardır. Hurwitz vd. (2013), BV ve kaynakları, mimarisi, yönetimi, analitiği, yorumlanması, gerçek zamanlı uygulamalara yansıması ve kuruluşların BV ile iş yapma şekillerinin değişimine yönelik kapsamlı bir araştırma yapmışlardır. Cao ve Manrai (2014), BV'yi teknik ve iş bakışlarından tanımlayarak pazar bölümlendirme, hedefleme, konumlandırma ile pazarlama karması geliştirmede BV'nin rolünü sunmuşlardır. Ayrıca, BV'yi kullanmanın zorluklarını ve geleceğini tartışmak üzere gerçek zamanlı sektör örnekleri verilmiştir. Edosio (2014), BV'yi geleneksel veri kümelerinden ayıran özelliklere genel bir bakış ile e-ticarette tüketici BV'sinin analizini sağlayan teknolojileri incelemiştir. Önde gelen e-ticaret tedarikçilerinin iş stratejilerinde/faaliyetlerinde BV analitiği uygulamalarına ilişkin örnekler sunulmuş, karşılaşılan zorluklar belirlenmiştir. Salvador ve Ikedata (2014), pazarlama bilgi sistemleri bağlamında BV kullanımı, buna bağlı yeni olasılıklar ve sınırlamalar üzerine düşünmeyi amaçlamışlardır. $\mathrm{Bu}$ amaçla; stratejik (yapı, bölümlendirme, konumlandırma) ve operasyonel (pazarlama karması) karar verme bilgisi sunan bakışlarla BV kullanımı değerlendirilmiştir.

Altunışık (2015), BV’nin tanımını, kaynaklarını, popüler olma sebeplerini, mevcut uygulama sonuçlarını, zorluklarını, uygulamaların başarılı olabilme şartlarını literatür bilgileri dahilinde ele almıştır. Hadi vd. (2015), BV'nin içeriğini, özelliklerini, türlerini, mimarisini, teknolojilerini genel bir bakışla; Mishra ve Sharma (2015), BV'nin önemini, fırsatlarını, zorluklarını ve dünyadan temsili BV girişimlerini sunmuşlardır. Sravanthi ve Reddy (2015), BV'nin bankacılık, pazarlama, finans, tarım, kimya, sağlık, VM ve bulut bilişim alanlarındaki rolünü detaylı açıklamalarla ortaya koymuşlardır. Doğan ve Arslantekin (2016), veriyi kavramsal düzeyde incelemişler, veri tabanları ve veri ambarları yönüyle depolama sistemlerini, yönetimini, programlama gibi pek çok kavramla olan ilişkilerini, BV işlenirken kullanılan teknolojileri ve yöntemleri aktarmışlardır. Ayrıca BV ile ilgili farkındalığa sahip organizasyonlarda BV'nin kullanım alanlarına ilişkin örnekler vermişlerdir. 
Erevelles vd. (2016), BV'nin pazarlama faaliyetleri üzerindeki etkisini daha iyi anlamak ve işletmelerin bundan faydalanmalarını sağlamak üzere örneklerle fiziksel, beşeri ve örgütsel sermaye kaynaklarına dayanan kavramsal bir çerçeve önermektedirler. Mukherjee ve Shaw (2016), literatür taraması ile BV'nin tüm yönlerini ortaya koymuşlardır. BV analitiğinin ticari büyümeyi güvence altına almak üzere iş analistleriyle birlikte anlaşılır hale getirilmesini sağlayan görselleştirmeyi ve BV'nin kullanımını örneklerle somutlaştırarak kavramları anlaşılır hale getirmeyi amaçlamışlardır. Bunun yanı sıra nüfus sağlığı, finans, haberleşme, gıda için sahtekârlık tespiti ve duyarlılık analizi yapmak üzere BV'den faydalanılması gerektiğini öngörmüşlerdir.

Köseoğlu ve Demirci (2017), Türkiye'de BV ve VM'nin kamu politikalarındaki ve hizmetlerindeki etkilerini görebilmek üzere bakanlıkların stratejik planlarını ve üst politika belgelerini içerik analiziyle incelemişler; konuya dönük bir farkındalık olmasına karşın daha kapsamlı bir eylem planına ve stratejilere ihtiyaç duyulduğunu belirlemişlerdir. Memon vd. (2017) ve Su (2017), BV'de etkin ve ücretsiz bir çözüm sergilemek, avantajlarını ve kullanım kolaylığını göstermek üzere teknolojilerdeki yeni gelişmelerin analitik bir incelemesini gerçekleştirmişlerdir. BV ve önemi örneklerle açıklanarak ana teknolojik bileşenler özetlenmiş; bunların veri arşivlerinden bilgi almak ve bilinçli kararlar vermek üzere kullanımını sunmuşlardır. Sağıroğlu (2017) ve Sağıroğlu (2019), dünyada (daha çok Amerika) ve Türkiye'de BV çalışmalarını özetlemiş, çıkarımlar ve değerlendirmeler sunmuştur. Çalışmasında, Türkiye'de savunma sanayisinde açık erişimli çözümler üretildiğini ancak özel sektörde BV'ye yatırım yapılan girişimler olmasına karşın çözümler üretilmediğini belirtmiştir. Aktan (2018), BV'yi bileşenleri, veri kaynakları, uygulamaları, avantajları ve güvenlik sorunları bağlamında ele almış; BV analitiğini ve ileri analitik yöntemlerden Hadoop mimarisinin işleyişini incelemiştir. Baum vd. (2018), üretim-bakım alanında BV analitiğinin güncel durumunu, araştırma yönelimlerini, gelişimlerini ve BV niteliklerini içeren çalışmaları sınırlılıklarıyla birlikte özetlemişlerdir. Thulara vd. (2018), BV ile ilgili bütün temel işlevlere sahip olan arama motoru, sosyal medya ve e-ticaret şirketlerinin iş modellerine BV tekniklerinin uygulanmasını ve elde edilen avantajları sunmuşlardır.

Çark vd. (2019), Endüstri 4.0'ın gelişimindeki tetikleyici etkisi yönüyle BV'yi ve işletmeler üzerindeki etkilerini incelenmişlerdir. Ayrıca literatür taramasıyla ulaşılan bulgu ve bilgiler doğrultusunda bu etkileri değerlendirmişlerdir. Ersöz (2019), Türkiye'de BV ve analitiğinin farkındalığına ilişkin firma beklentilerine, problem çözümlerine ve önerilere yer vermiştir. Problemlerin çözümü için karar ağaçları (imalat, tarım makineleri, bankacılık sektörlerinde) ve kümeleme analizi (e-ticaret, iş makineleri ihracatı sektörlerinde) algoritmaları olmak üzere VM yöntemleri kullanılmıştır. Koltan Yılmaz (2019), bilim, sağlık, akıllı şehir, devlet yönetimi, hayvan koruma, deprem tahmini, ulaşım konularındaki uygulamalarla işletmelere fikir verebilecek BV örneklerini özetlemiş ve kullanılan verileri, yaklaşımları ve zorlukları ortaya koymuştur. Marr (2019), sağlık, kamu, konaklama, üretim, pazarlama, perakende, sosyal medya, iletişim, tarım, moda, spor, bilişim, finans gibi pek çok sektörden dünyaca ünlü 45 büyük işletmenin BV kullanımını, elde edilen değerleri ve işletmelerin dijital dönüşümlerini özetlemiştir. Aytaç ve Bilge (2020), Türkiye'de Ankara ilinde BV analitiği çözümleri sunan 10 kurumu incelemişler ve ekip liderleriyle yapılan mülakatlar sonucunda mevcut durumlarını, üniversitelerin ilgili bölümlerinden ve öğrencilerinden beklentilerini ortaya koymuşlardır. Ayvaz ve Salman (2020), BV'nin Türkiye'deki kullanım olgunluğunu belirlemek üzere farklı sektörlerden elde ettikleri verilerle işletmelerin BV hazırlıklarını ve kullanım derecelerini ölçmüşler; görselleştirme araçları ve betik dillerin kullanımının yaygınlaştığını belirlemişlerdir. Eravcı (2020), BV altyapısı oluşturmak üzere Türkiye Cumhuriyeti Cumhurbaşkanlığı öncülüğündeki dijital dönüşümün ve BV'nin kurumlara etkisini ele almış, teknolojilerini açıklamış, zorluklar ve riskler için çözümler önermiştir. Onay (2020), BV ve analitiğini kavramsal olarak incelemiş ve bu kavramların dijital dönüşüm sürecinde işletmelere sağladığ1 faydaları ele almıştır. Ayrıca makalede BV Çağında iç denetim mesleğinin yaşadığı dönüşüm 
açısından mesleğin gelişen ve değişen rolüne yer verilmiştir. BV'nin denetim faaliyetlerine etkisi ve iç denetim fonksiyonunun BV analitiğiyle nasıl değer yaratabileceği değerlendirilmiştir.

Yukarda özetlenen çalışmalar (27 çalışma) incelendiğinde, işletmelerde BV kullanımının pek çok alanda ortaya çıktığı, bununla birlikte uygulamaların çoğunlukla teorik kavramlarla açıklandığı belirlenmiştir. Kaynaklar Türkiye'de BV kullanan işletmeler açısından değerlendirildiğinde, kamu sektöründe dört çalışma (Köseoğlu ve Demirci, 2017; Sağıroğlu, 2017; Sağıroğlu, 2019; Eravc1, 2020) olduğu görülmektedir. Özel sektörde ise üç çalışma (Ersöz, 2019; Aytaç ve Bilge, 2020; Ayvaz ve Salman, 2020) bulunmasına karşın bu çalışmalar işletmelerin farkındalığını, beklentilerini, analiz yöntemlerinin uygunluğunu ve çözüm önerilerini içermektedir.

Çalışmaların \%41'inde (11 çalışma) gerçek zamanlı işletme uygulamalarına yer verilmiştir. $\mathrm{Bu}$ uygulamalarda yer alan işletmeler, doğrudan iş modeli uygulamalarıyla ya da BV'nin alandaki rolünü açıklamak üzere çalışmalarda yer almaktadır ve Tablo 1'de gösterilmektedir.

Tablo 1. Literatürdeki Çalışmalarda Yer Alan İşletmeler

\begin{tabular}{|c|c|c|}
\hline Yazar & Çalıșma & Örnek İşletmeler \\
\hline Davenport ve Dyche (2013) & Araştırma raporu & $\begin{array}{l}\text { UPS, Caesars Entertainment, United Healthcare, Property and } \\
\text { Casualty Insurer, Macys.com, Bank of America, Sears, General } \\
\text { Electric, Schneider National, GroupM. }\end{array}$ \\
\hline Cao ve Manrai (2014) & Makale & Google, Netflix, Rocket XL, Walmart. \\
\hline Edosio (2014) & Araştırma raporu & Adidas, Walmart, Amazon. \\
\hline Doğan ve Arslantekin (2016) & Makale & PriceStats, Walmart, Barnes \& Noble, World Cup 2014 Brazil. \\
\hline Erevelles vd. (2016) & Makale & Southwest Airlines, Netflix, Google, Amazon, Ford, Epagogix. \\
\hline $\begin{array}{l}\text { Sağıroğlu (2017); } \\
\text { Sağıroğlu (2019) }\end{array}$ & $\begin{array}{l}\text { Çalıştay kitap } \\
\text { bölümü; } \\
\text { Bildiri }\end{array}$ & $\begin{array}{l}\text { Walgreens, Kroger, Southwest Airlines, Huffington Post, UPS, } \\
\text { American Express, Tesla, Ford, Bank of America, Duetto, } \\
\text { eBAY, Caesars Entertainment, General Electric, Google, Uber, } \\
\text { Norfolk Southern, Procter\&Gamble, Walmart. }\end{array}$ \\
\hline Thulara vd (2018) & Makale & Google, Amazon, Facebook, Twitter. \\
\hline Koltan Y1lmaz (2019) & Bildiri & $\begin{array}{l}\text { Zoological Society of London, Terra Seismic, Apixio, } \\
\text { Transport for London. }\end{array}$ \\
\hline Marr (2019) & Kitap & $\begin{array}{l}\text { Walmart, Netflix, Rolls Royce, Shell, Facebook, Microsoft, } \\
\text { IBM, BBC, Caesars Entertainment, Google, Walt Disney, } \\
\text { Twitter, Uber, Amazon, Apple, General Electric. }\end{array}$ \\
\hline Onay (2020) & Makale & Ayata, OfficeMax, Walmart \\
\hline
\end{tabular}

Tablo 1 incelendiğinde, çalışmalarda Dünya'dan çok sayıda özel sektör işletme örneği bulunmasına karşın Türkiye' deki özel sektör işletmelerinde BV uygulamalarını içeren bir çalışmanın olmadığı görülmektedir. Çalışmanın bu yönüyle konuya ve literatüre katkı sağlaması beklenmektedir.

BV işletme dışında, finans-bankacılık (Begenau vd., 2018; Sravanthi ve Reddy, 2015; Subrahmanyam, 2019), sağlık (Birinci, 2015; Austin ve Kusumoto, 2016; Massie vd., 2014; Memon vd., 2017; Schulte, 2018; Sanchez ve Verspoor, 2014; Stokes vd.,2016), ziraat (Kamilaris vd., 2017; Keeso, 2014; Ma vd., 2015; Majumdar vd. 2017;), kamu (Ali vd., 2016; Cousins, 2018; Forsdick, 2019; Koltan Y1lmaz, 2019; Scola, 2013; Tomar vd., 2016), ve eğitim (Jacqueleen, 2015; Sin ve Mthu, 2015; West, 2012) gibi alanlarda da kullanılmaktadır. Bu alanlara ilişkin örnekler Tablo 2'de gösterilmiştir.

Tablo 2. Alanlara Göre Büyük Veri Uygulamaları

\begin{tabular}{ll}
\hline Alan & \multicolumn{1}{c}{ Uygulama Konusu } \\
\hline \multirow{2}{*}{ İşletme } & $\begin{array}{l}\text { Kişiselleştirilmiş ürün ve hizmet sunma, müşteri memnuniyeti, müşteri kaybının önlenmesi, mobil pazarlama } \\
\text { uygulamaları, pazarlama bilgi sistemleri, pazarlama karması ve pazarlama stratejileri geliştirme, pazar }\end{array}$ \\
& $\begin{array}{l}\text { bölümlendirme, sosyal medya uygulamaları ve reklam, e-ticaret uygulamaları, gerçek zamanlı teklifler, stok } \\
\text { yönetimi, süreç optimizasyonu, bankacılık uygulamaları, ürün talep tahmini, ürün ve iş geliştirme, iç denetim } \\
\text { uygulamaları, maliyetleri düşürme, verimliliği artırma, marka iş birlikleri, yatırım kararları alma. }\end{array}$ \\
\hline \multirow{2}{*}{$\begin{array}{l}\text { Finans- } \\
\text { Bankacılık }\end{array}$} & $\begin{array}{l}\text { Karmaşık borsa hareketlerinin analizi, küresel finansal kararlar alma, alım satım, hile-suiistimal önleme, saldırı } \\
\text { tespiti, risk analizleri, yeni kredi başvurularını değerlendirme, mevcut müşteriler için kredi puan analizi, } \\
\text { yatırımcı analizi, hisse senedi tahmini. }\end{array}$ \\
\hline
\end{tabular}




\begin{tabular}{ll}
\hline \multirow{2}{*}{ Sağlık } & $\begin{array}{l}\text { Tibbi görüntüleme ve raporlama, klinik karar destek sistemleri, sağlık durumu analizi ve teşhis, optik karakter } \\
\text { tanıma teknolojisi, erken uyarı işareti, giyilebilir sensör entegrasyonu, hastalı tahmini, halk sağlığının } \\
\text { gözlemlenmesi, mobil sağlık hizmetleri, hastalıkların genetik temellerinin tespiti, bulaşıcı hastalık risk haritaları, } \\
\text { hasta merkezli eczane hizmetleri, ilaç formül yönetimi ve ilaç güvenliği. }\end{array}$ \\
\hline Ziraat & $\begin{array}{l}\text { Hava durumu tahmini, iklim değişikliği modellemeleri, gida güvenliği, topraktaki değişkenlik ölçümü, mahsul } \\
\text { üretimi, çiftçi bilgi sistemleri, arazi yönetimi, hayvan temelli araştırmalar. }\end{array}$ \\
\hline \multirow{2}{*}{ Kamu } & $\begin{array}{l}\text { Nüfus sayımı, enerji kullanımı, bütçe raporları, yasal yaptırımların sonuçları, veri paylaşımı ve gizliliği, acil } \\
\text { müdahale, ihtiyaç tespiti, akıllı şehirler, güvenlik sistemleri, hava ve su kirliliğini önleme, vergilendirme, altyapı } \\
\text { düzenlemeleri, trafik sorunlarının çözümü, müşteri seyahat haritalaması, bireysel seyahat planlaması, bölgesel } \\
\text { ücret sistemi, toplum gelişimi üzerindeki etkilerin incelenmesi, yönetişim düzenlemeleri, istismar tespiti. }\end{array}$ \\
\hline \multirow{2}{*}{ Eğitim } & $\begin{array}{l}\text { Çevrimiçi öğrenme ve harmanlanmış öğrenme uygulamaları, ölçme ve tahmine dayalı değerlendirme, okuma ve } \\
\text { öğrenme yazılımları, gösterge tabloları ve görsel ekranlar üzerinden performans izleme, performans ve yetenek } \\
\text { tahmini, öğrenci davranış tespiti. }\end{array}$ \\
\hline
\end{tabular}

Tablo 2 incelendiğinde, BV'nin hemen her alanda derin etkilere sahip olduğu görülmektedir. $\mathrm{Bu}$ doğrultuda, Türkiye'de BV'ye yönelik en büyük dönüşüm sağlık alanında yaşanmaktadır. Alandaki en önemli örnek, en bilineni ve başarılı olanı "e-nabız" olmak üzere, içerisinde pek çok modül barındıran Ulusal Sağlık Sistemi (Birinci, 2015) uygulamasıdır.

\section{BÜYÜK VERİ}

BV, teknolojik gelişmelere bağlı bir hedeftir ve verinin analiz edilme biçimini değiştirmektedir. 19. Yüzyıldan itibaren büyük ve karmaşık veriler için örnekleme yöntemine başvurulmaktadır ki bilginin az olduğu ve dijital teknolojinin yaygınlaşmadığı bir dönemde bu doğaldır. Ancak teknolojik gelişmeler, verilerin tamamını (anakütle) kullanma ve sınırlı miktarda veri ile elde edilemeyecek ayrıntıları bulma firsatı vermekte; BV analizi alt kategorilerin çok daha net ifade edilmesini sağlamaktadır (Çelik, 2018:14). Diğer taraftan bilimde yaşanan değişim ile birlikte öne çıkan doğrusallık varsayımı da, hipotezlerle işe başlayıp kurama ulaşma, aykırı değerleri önemsiz sayma gibi yöntemleri eleştirmektedir. Hipotezlere kıyasla "veri ile işe başlayıp bu verilere uygun desenleri, korelasyonları bulmanın daha doğru olacağı" konusu ön plana çıkmaktadır (Gürsakal, 2017:185).

BV analizi, özünde kestirimlerle ilgili olup bilgisayar biliminin YZ araştırmaları içinde yer alan makine öğrenmesi algoritmalarının bir parçası olarak da tanımlanabilmektedir. Ancak burada, bilgisayarlara insanlar gibi düşünmeyi öğretmek yerine çok fazla miktardaki veriden olasılıklar çıkarmak üzere gerçekleştirilen matematiksel uygulamalar ön plana çıkmaktadır. Bir e-postanın "istenmeyen e-posta olma olasılığı" ya da "büyüük" olarak girilen sözcüğün "büyük" olduğunun varsayılması gibi durumlarda anahtar konu, bu sistemlerin kestirimlerini dayandırdıkları çok miktarda veriye sahip olmaları ve bu nedenle daha iyi performans göstermeleridir (MayerSchönberger ve Cukier, 2013:19).

BV hem süreç hem de varlık olarak değerlendirilmektedir. Süreç olarak Bilgi İşlem Teknolojileri (BİT) işletmelerinin elde ettiği, depoladığı, analiz ettiği farklı yapılardaki verileri; varlık olarak klasik veri tabanı sistemleri ve yazılım teknikleriyle işlenemeyen veri miktarlarını kapsamaktadır (Demirtaş ve Argan, 2015:4). Bu nedenle, veri çeşitli yapılarda ve geleneksel yöntemlerle işlenemeyecek düzeydeyse "büyük" olarak nitelendirilmekte; bu büyüklük hız kavramını da kapsamaktadır. Bu yönleriyle BV; hacim (volume), hız (velocity), çeşitlilik (variety), olmak üzere üç bileşenle (Aksu, 2017:50; Ali vd, 2016:3; Baum vd, 2018:1; Cao ve Manrai, 2014:23; Çiğdem ve Seyrek, 2015:4; Erevelles vd., 2016: 898; Fayyad, 2016:25; Gobble, 2013:64; Hurwitz vd, 2013:10; Mukherjee ve Shaw, 2016:66; Tomar vd, 2016:17; Salvador ve Ikedata, 2014:78; Su, 2017:2) tanımlanmaktadır. Bu bileşenler aşağıdaki gibi açıklanabilir. 
Hacim, üretilen verinin kapasitesini göstermekte ve elektronik ortamda en küçügü bit ${ }^{1}$ olan birimlerle ölçülmektedir. Veri miktarı belirli rakamlarla sınırlanmasa da "standartları sınırları aşan, normalden çok büyük" (Fayyad, 2016:25) ya da "Terabyte (TB)'dan Zettabyte (ZB)'a kadar veri boyutuna sahip veri setleri” (Su, 2017:2) BV olarak ifade edilmektedir. Veri miktarının 2025 yılına kadar 175 ZB'ye çıkacağı öngörülmektedir (Reinsel vd., 2018:6). Hız, verinin gelme oranını göstermektedir. Verinin üretilmesi durdurulamamakta, veri yeniden işleme alınamamaktadır (Fayyad, 2016:25). BV hızı ile nitelendirilebilir, veri üretim sıklığı ve dağıtım sıklığı ile ölçülür (Onay, 2020: 136). Hız, hacimden daha önemli hale gelebilmektedir. Yüksek yenilenme hızına sahip işlemlerden elde edilen büyük hacimde veri, yüksek hızda veri akışlarına neden olmakta; akış süresi de çok kısa olmaktadır (Su, 2017:2; Satı, 2015:605). Bu konuda, toplu işlemden gerçek zamanlı işleme değişim söz konusudur. Gerçek zamanlı sınırlı veri, düşük hızlı veriden daha etkin olabilmektedir (BBVA, 2020). Çeşitlilik ise veri kümesindeki yapısal heterojenliği belirtmektedir. BV'de her türden veri akışı gerçekleşmekte ve bunlar yapılandırılmış, yarı-yapılandırılmış, yapılandırılmamış olarak gruplandırılmaktadır. Dünyadaki verilerin \%80-90'ının yapılandırılmamış olması, BV'nin öneminin artmasının önde gelen nedenlerinde biridir (Aktan, 2018:4; Gürsakal, 2017:56; Demirezen, 2017:132; Özdoğan, 2016:15). Yapılandırılmış veriler (sayısal, para birimi, alfabetik, isim, fatura, sınav sonuçları, e-devlet verileri, tarih veya adres vb.), sabit formatta saklanabilen, erişilebilen, işlenebilen; yapılandırılmamış veriler (fotoğraflar, ses dosyaları, videolar, PDF, HTML ve web günlükleri vb.), geleneksel grafik ya da tablolara kolaylıkla yerleştirilemeyen, etiket (\#tag) ile özetlenen verilerdir (Çelik, 2018:85-86; Gürsakal, 2017:54; Guru99, 2019). Yarı yapılandırılmış veriler (XML, HTML-etiketli metin, mp3, video, doktor reçetesi vb.) ise iki veri biçimini de içerebilir, bütün veri aynı yapıda değildir (Gürsakal, 2017:55).

BV'yi benzersiz kılan üç temel özelliğine ek olarak, daha kapsamlı değerlendirmeler yapıldığında, BV'nin bileşenlerinin sayısı değer (value) ve geçerlik-doğrulanabilirlik (veracityverification) bileşenleri (Aktan, 2018; BBVA, 2020; Çelik, 2018; Gürsakal, 2017; Hadi vd., 2015:20; Memon vd, 2017:45; Mishra ve Sharma, 2015:28; Onay, 2020:134; Özdoğan, 2016:12; Sat1, 2015:605) ile birlikte beşe çıkmaktadır. Bu bileşenler Şekil 1'de gösterilmektedir.

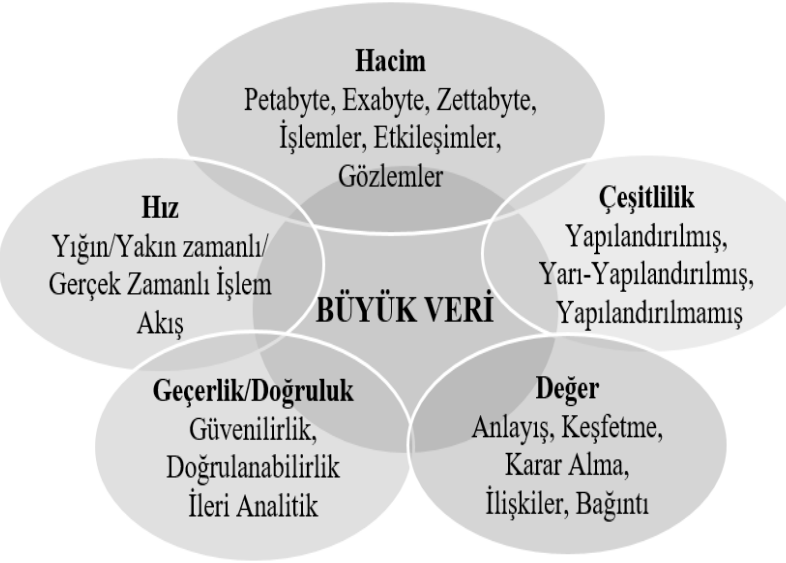

Şekil 1. Büyük Veri Bileşenleri (Onay, 2020:134)

Değer, hedeflenen analiz/hipotez etkinliği ya da öngörüsü için verinin katma değerini tanımlamaktadır (Hadi vd, 2015:21). BV'den elde edilen bu katma değer daha sonra yeni değerler elde etmeye de olanak sağlamalıdır (Mayer-Schönberger ve Cukier, 2013:2013:111). Bu da depolanan verilerin işlendikten sonra tekrar analiz edilebilmesiyle mümkündür (Atalay ve Çelik, 2017:163; Terzi vd, 2017:21). BV'nin en önemli özelliği değer yaratabilme gücüdür. Böylece, işletmelerin karar yetenekleri güçlenmekte, süreçler optimize edilebilmekte ve içgörü, önsezi ya da

${ }^{1}$ Bit (b): 1 ya da 0; Byte (B): 8bit; Kilobyte (KB): $10^{3}$ byte; Megabyte (MB): $10^{6}$ byte; Gigabyte (GB): $10^{9}$ byte; Terabyte (TB): $10^{12}$ byte; Petabyte (PB): $10^{15}$ byte; Exabyte (EB): $10^{18}$ byte; Zettabyte (ZB): $10^{21}$ byte; Yottabyte (YB): $10^{24}$ byte 
kavrayış olarak tanımlanan tahmin yeteneklerini geliştirmek sağlanabilecektir (Onay, 2020: 137). Geçerlik/Doğrulanabilirlik, karar verme süreçlerinde bilgiye güvenilme derecesidir. Verinin doğru kaynaktan alınıp alınmadığı, nasıl elde edildiği, buna bağlı olarak da doğru korelasyonları bulmak işin geleceği için çok önemlidir (Ariely, 2019:12; Çelik, 2018:51; Hadi vd, 2015:21; Sat1, 2015:605). BV'nin doğruluğunu olumsuz etkileyen faktörler, analizlerde gerçek değerin ortaya konulmasını engellemektedir (Terzi vd, 2017:20). BV'nin kalitesi, geleneksel veriye göre yüksek olmakla birlikte BV'nin özellikleri güçlü analitik teknikler ile bir araya getirildiğinde, doğruluk geleneksel yöntemlerle kıyaslanamayacak seviyelere yükselmektedir (Onay, 2020: 136).

BV kaynakları, temel olarak insanlar tarafindan üretilen dijital izler ve makinelerden gelen verilerden oluşmaktadır. Dijital izler, insanların internet etkileşimlerinden kaynaklanan verilerdir. $\mathrm{Bu}$ izler; çeşitli ağ cihazları ve bilgisayarlar aracılığıyla, güvenlik/denetleme dosyalarından kullanıcıların alışveriş sitesinde sepete eklediği bir üründen vazgeçip silmelerine kadar olan bütün süreçte kayıt altına alınmaktadır. Bu kayıtlardan da makine verileri üretilmektedir (Ergen; 2018:56). Nesnelerin İnterneti (NI) (Internet of Things (IoT)) olarak tanımlanan cihazlardan gelen gerçek zamanlı veriler, işletmelerin faaliyetleri sonucu üretilen veriler ve elektronik dosyalar da yine BV'nin kaynakları arasındadır (Hadoop, 2021). Bu kaynakların doğru kullanılmasıyla daha fazla kestirimde bulunulabilmekte ve böylece BV'den öngörülemeyen bilgiler elde edilebilmektedir. Bu durum, işletmeler açısından daha fazla değer yaratılmasını sağlayabilmektedir (Atalay ve Çelik, 2017:163).

\section{BÜYÜK VERIYLE DEĞER YARATAN IŞSLTMELER}

BV çalışmalarının odak noktasında, veriyle nasıl fayda yaratılabileceği yer almalıdır. BV analitiği veriden faydalanılmasını sağlar. Bunun için işletmeler, daha önceden kullanılmış ya da kullanılmamış verileriyle yeni bilgiler ve içgörüler elde etmek üzere YZ ve VM tekniklerini (metin analitiği, makine öğrenmesi algoritmaları, doğal dil işleme, tahmine dayalı analitik gibi) kullanmaktadır. Teknolojik araçlar, BV analizinde algoritmik doğruluğu ve hesaplama gücünü en üst seviyeye çıkarmaktadır (IBM, 2021; Onay, 2020:137). Yakın zamana kadar BV analizi yapan işletmeler genellikle BİT işletmelerinden oluşmaktaydı. Ancak BV'nin depolanması ve işlenmesi konusundaki teknik zorlukların sona ermesi ve BİT işletmelerinin BV analizini hizmet olarak sunmaya başlamasıyla birlikte bütün sektörler için rekabet avantajı, daha iyi karar verme, yeni ürün/hizmet geliştirme, kalite ve verimliliği artırma, müşteri ve pazar dinamiklerini daha iyi anlama gibi faydalar yaratan uygulamalar artmıştır (Akınc1, 2019:27).

$\mathrm{Bu}$ çalışmada, kaynak araştırması ile elde edilen bilgiler doğrultusunda Türkiye'de özel sektörde BV ile değer yaratan işletmelerin uygulamaları incelenmiş ve değerlendirilmiştir. Uygulamalar, akademik kaynaklarda daha önceki çalışmalarda yer almadığı için bilgiler işletmelerin ve çözüm ortaklarının kurumsal web sayfalarından, işletmelerin üst düzey yöneticilerinin beyanlarının yer aldığı yayınlardan ve raporlardan, teknoloji ve pazarlama içerikli güvenilir web sayfalarından elde edilmiştir. Bu kaynaklarda, BV başarıları kapsamlı olarak paylaşılan işletmeler incelenmiş; perakendecilik, e-ticaret, bankacılık ve enerji sektörleri olmak üzere BV ile iş modellerini değiştirmeyi hedefleyen dört işletmeye ulaşılmıştır. Bu işletmelerin $\mathrm{BV}$ ile elde ettikleri değerler aşağıda sunulmaktadır.

BOYNER GRUP: Çok katlı mağazacılık, özel marka, e-ticaret ve mobil uygulama ile hizmet veren Türkiye'nin lider mağaza ve moda perakendesi grubudur. BV çalışmaları, akıllı telefonlara yüklenen mobil alışveriş uygulaması ile yön bulmuştur. Bu yazılımla müşterilerin gün içindeki hareketleri, hangi ürünlerle ilgilendikleri, hangi sayfalarda uzun zaman geçirdikleri, konum bilgileri tespit edilebilmektedir. Bu yolla elde edilen değerler şöyledir (Boyner, 2017: 53-62):

BV'de amaç, müşterinin davranışlarını tanımak ve anlamlandırmaktır. Bu doğrultuda, yeni açılan mağazalarının ve mobil uygulamanın müşteri profilleri arasındaki benzerlikler belirlenmiş, 
mağaza civarında oturanlar seçilmiş, daha sonra mağazanın yakınından geçmekte olan müşterilere tanıtım mesajları gönderilerek paracık olarak adlandırdıkları ödül-puan sistemi hediye olarak sunulmuştur. $\mathrm{Bu}$ davet ile cironun \%27'si elde edilmiştir. Bir diğer analizde, 24 saatlik alışveriş hareketleri incelenmiş, internet üzerinden alışverişlerin en yoğun 06.00-10.00 aralığında yapıldığ1 bilgisi elde edilmiştir. Isı haritası olarak nitelendirdikleri bu işlemlerin mahalle, sokak, köy, kasaba dahilinde hangi şehirlerde gerçekleştirildiği saptanmış; böylece sadece harcamalar değil alınan ürünün türü, rengi, bedeni gibi bilgilere de erişmek mümkün olmuştur. Bu detayları takip edebilmek müşterilere yapılabilecek cazip tekliflerin sunulması açısından BV'nin temelindeki en önemli becerilerdendir. Müşteriler tarafindan avantajların fark edilmesiyle daha önce $\% 50$ civarında olan mobil uygulama konum bilgisi paylaşımı iki yıllık sürede \%70'e ulaşmıştır.

BV, doğru zamanda doğru müşteriye ulaşılabilmeyi de sağlamıştır. Bir ürünün ne kadar sürede tekrar satın alındığı, yılın hangi dönemlerinde satın almanın tekrarlandığ ya da arttığı analizle ortaya çıkarıldığında mobil sistem üzerinden kasada gerçek zamanlı teklif yapabilmek mümkün olmuştur. Örneğin daha önce satın alınan bebek kıyafetinin beden bilgisiyle, bebeğin ne kadar sürede hangi bedene ulaşabileceği bilgisi birleştirildiğinde, doğru zaman geldiğinde müşteriye en iyi teklif sunulabilmektedir. Ya da mağazadan yapılan bir alışveriş ödemesi sonrasında " $X$ miktar paracık kazandınız, bunu sizin en çok sevdiğiniz $Y$ ürününde, paracığın $Z$ katı değeri ile kullanabilirsiniz" şeklindeki gerçek zamanlı teklif mesajı mobil uygulamayla müşteriye iletilebilmektedir. Müşteriye indirim yerine paracık verme ön plana çıkarıldığında, paracığın daha sonraki hareketleri de tespit edilebilmekte ve yeni satışlara yönlendirme yapılabilmektedir. Örneğin, beacon ${ }^{2}$ aracılığıyla ayakkabı reyonunda uzun zaman geçirdiği tespit edilen ve kasada işlem gerçekleştirmeyen bir müşteri için "ayakkabı reyonunda 15 dakika geçirmiş, problemini çözememiş, ayakkabı alma ihtimali $\% 65$ 'ten \%85'e çıktı" ilişkisi kurulabildiğinde, müşteriye "Mağazadan çıktıktan sonra sağ taraftaki $A$ mağazasında aradığınız ayakkabıyı bulabilirsiniz, bu alışveriş için $X$ miktar paracık kullanabilirsiniz" mesajı gönderildiğinde, hem müşterinin alışveriş olasılığı hem de $A$ markasının envanterinden satış yapma olasılığg yükselmektedir.

Diğer taraftan şirket kendi verilerinin yanı sıra işletme dışı verilerden de faydalanmaktadır. Örneğin, hava durumu verileri kullanılarak satın alma potansiyelinin ve müşteri ilgisinin yüksek olduğu zamanlarda, hatırlatma ve önerilerle satış oranları yükseltilebilmiştir. Yağış beklenen günlerde müşteri bilgilendirilerek mont kategorisine yönlendirilmiş, bunun sonucunda kullanıcıların \%85'inin mont kategorisini ziyaret etmesi sağlanmıştır. Bu uygulama sayesinde satışlarda \%50'yi aşan bir artışa ulaşıldığı tespit edilmiştir. Bu tür uygulamalar ile fiziksel mağazalar ve e-ticaret pazarlama stratejilerini birleştirmek mümkün olmuştur (TheBrandage, 2021).

BV'den elde edilen örüntüler sayesinde, müşteri kaybı gerçekleşmeden riski görüp zamanında hareket alabilmeyi sağlayan modeller geliştirilmiş, hangi müşterinin ne zaman pasifleşebileceği belirlenmiş, özelleştirilmiş teklifler sayesinde müşteri geri kazanılabilmiş, müşteri kayıp oranında düşüş kaydedilmiştir (SAS, 2021a). Gelecek hedeflerine ulaşmak için veri odaklı büyüme, giyilebilir teknolojiler, sanal giyinme odaları, artırılmış ve sanal gerçeklik uygulamaları gibi deneyim odaklı içerik çalışmaları yürütülmektedir (Pehlivan, 2019).

YEMEKSEPETİ (yemeksepeti.com): Çevrimiçi yemek siparişi hizmeti sunan web sitesidir. Paket servisi bulunan restoranlar ve yemek sipariş etmek isteyen internet web kullanıcılarını buluşturmaktadır. Mobil uygulaması da bulunan şirket, 2020 itibariyle 78 bini geçen restoran ve 19 milyonu geçen kullanıcısı ile Türkiye'de en çok kullanılan yemek sipariş ortamıdır (Yemeksepeti, 2020). BV ile geliştirdiği özgün iş modeli, şirketin başarısının ve büyümesinin özünü oluşturmaktadır.

\footnotetext{
${ }^{2}$ Bluetooth dalgaları yoluyla akıllı cihazlara sinyaller gönderebilmekte ve insanları tespit etmek için yakınlık teknolojisini
} kullanmaktadır. 
Yemek siparişinde zaman çok önemli bir faktördür ve hizmetin 30-40 dk. içerisinde tamamlanması beklenmektedir. Ayrıca yemek yeme; görünce sipariş verme, yemeyi isteme şeklinde gelişebilen duygusal ve dürtüsel bir davranıştır. Bu da sektörel bazda her türlü değişikliğin takip edilmesini, iş ve teknik birimlerin hızlı cevap vermesini gerektirmektedir. Bilinmeyen ilişkiler analizle ortaya çıkarılmaktadır (Akar, 2016). Şirketin BV'sine konu olan önemli bazı kategoriler Tablo 3'de verilmektedir.

Tablo 3. Yemek Sipariş Sitesi 2015-2019 Verileri (Yemeksepetiblog, 2021)

\begin{tabular}{ccccccl}
\hline Yıl & $\begin{array}{c}\text { Restoran } \\
\text { Sayısı } \\
\text { (bin) }\end{array}$ & $\begin{array}{c}\text { Kullanıcı } \\
\text { Sayısı } \\
\text { (milyon) }\end{array}$ & $\begin{array}{c}\text { Sipariş } \\
\text { Miktarı } \\
\text { (milyon) }\end{array}$ & $\begin{array}{c}\text { Mobil } \\
\text { Sipariş Oranı } \\
(\mathbf{\%})\end{array}$ & $\begin{array}{c}\text { En Çok } \\
\text { Sipariş Verilen } \\
\text { Ürünler }\end{array}$ & $\begin{array}{c}\text { Siparişi } \\
\text { En Çok Artan } \\
\text { Ürünler }\end{array}$ \\
\hline 2019 & 46 & 14 & 340 & 81 & Lahmacun, döner, kebap & Tavuklu pilav, kahve, limonata \\
\hline 2018 & 27 & 11 & 250 & 75 & Burger, döner, lahmacun & Kahve, deniz ürünleri, çiğ köfte \\
\hline 2017 & 22 & 8 & 190 & 69 & Burger, lahmacun, kebap & Kahve, pilav, dondurma \\
\hline 2016 & 17 & 6 & 134 & 62 & Lahmacun, burger, kebap & Dondurma, kahvalt1, börek \\
\hline 2015 & 14 & 4,3 & 92 & 50 & Döner, burger, pizza & Çiğ köfte, lahmacun, kahvalt1 \\
\hline
\end{tabular}

Tablo 3 incelendiğinde, restoran ve kullanıcı sayılarında, sipariş miktarında ve siparişler içerisinde mobil siparişlerin oranında önemli seviyedeki artış dikkat çekmektedir. Şirketin hizmetine konu olan ürünler "çok sipariş verilen" ve "siparişi en çok artan" olmak üzere tabloda yer almaktadır. $\mathrm{Bu}$ doğrultuda verinin miktar, hız ve çeşitlilik bileşenleriyle büyüklüğü de gözlemlenebilmektedir. Mobil sipariş oranı, Türkiye'de 2020 yılında yapılan çevrim içi alışverişin \%55'inin mobil uygulamayla gerçekleştirildiği (Iyzico, 2021) göz önünde bulundurulduğunda, şirketin kullanıcılara ikna edici şekilde ulaşabildiğini göstermektedir. Tablodaki veriler dışında, kullanıcıların kişisel, demografik, sipariş, konum, yorum ve puanlama verileri kullanılarak kişiselleştirilmiş hizmet, reklam/pazarlama çalışmaları, ürün ve iş geliştirme konularında başarılı olunduğu söylenebilir.

Şirket, BV'siyle, Türkiye'nin bir günlük beslenme alışkanlığına da 1şık tutacak bir ilişki belirlemiştir. Genel olarak, kahvaltıda sıkı bir başlangıç (kahvaltı tabağı, Ayvalık tostu, portakal suyu), öğle menüsünde hızlı yemekler (burger, patates kızartması, sufle) akşam menüsünde ise geleneksel yemekler (mercimek çorbası, döner, lahmacun) tercih edilmektedir Akşam 20-23 arası verilen siparişler günün geri kalanının iki katını oluşturmaktadır (Yemeksepetiblog, 2018). BV'nin anlam kazanması, bu tür örüntülerin belirlenmesi ile mümkündür. Örneğin, kullanıcıların izlediği televizyon programları siparişleri etkilemektedir. Yerleşim yerinden uzakta hayatta kalma mücadelesi verilen $X$ yarışma programının olduğu gün, kazanan takımın pizza ödülü aldığı saatlerde, pizza siparişlerinin öncekilere oranla \%29 arttı̆̆1, burger ödülü olduğunda ise burger siparişlerinin \%19 arttığı tespit edilmiştir. Siparişte artan bu anormalliğin nedeni belirlendikten sonra yapılan medya çalışmalarıyla yarışma heyecanı başlamadan önce sipariş verme sağlanabilmiştir (Akar, 2016). Bir başka örüntüde, her iki kullanıcıdan birinin en az bir kere de olsa pizza siparişi verdiği, \%33'ünün 19-24 yaş grubundan oluştuğu, \%70'inin erkekler tarafindan verildiği, siparişin en çok hafta sonu gerçekleştiği, kışın verilen siparişlerin yaza göre \%60 artış gösterdiği belirlenmiştir. Ayrıca, üniversite öğrencilerinin sınav haftalarında ve derbi maçlarının olduğu günlerde de siparişler önemli ölçüde artmaktadır (Yemeksepetiblog, 2016a). Bu türdeki BV örüntüleri doğrultusunda, müşteriler için indirimler sunulabilmiş, talepler zamanında karşılanabilmiş, yatırım kararları alınabilmiş, marka iş birlikleri sağlanabilmiş ve medya planlaması daha etkin şekilde yapılabilmiştir.

Yemeksepeti'nin en popüler BV başarısı, şirkete ödüller kazandıran "Fakat İyi Yedik" projesidir. Proje, kullanıcıların kişiselleştirilmiş verilerinin sunulduğu bir mikrositeden oluşmaktadır. BV'deki 10 milyar veri, anahtar kategorilerle 1,5 milyara indirgenmiş; kişinin siparişleri, yeme alışkanlıkları, ilginç yemeksepeti verileri ve eğlenceye dönük sorular kullanıcıya video olarak sunulmuştur. BV, istek anında oluşan, her siparişle yenilenen dinamik bir formata dönüşmüştür. $\mathrm{Bu}$, BV'nin görselleştirilmesi açısından önemli bir başarıdır. Proje sonucunda mikrositeye 1,5-2 aylık sürede 630 bin ziyaret, 212 bin video, 2 milyon sayfa görüntüleme, 5 binden fazla Twitter mesajı geri 
bildirim olarak dönmüştür. Böylece şirket markasını sunabilmiş, viral pazarlama ya da ağızdan ağıza reklam olarak bilinen müşteri odaklı pazarlama faydası sağlamıştır (Akar, 2016).

Şirket, BV'si ve tecrübeleri sayesinde, iş ortağı restoranlara daha iyi servis verme, doğru ürün sunma, pazarlama ölçümleri gibi konularda danışmanlık hizmeti vererek de fayda sağlamaktadır (Yemeksepetiblog, 2016b).

Yemeksepeti'nin BV'si tamamen farklı başka bir ortamda, bir kent tasarımı çalışmasında da (BilgeK., 2017) değer yaratmayı başarmıştır. Çalışmada yemeksepeti.com verileri, kullanıcı izleriyle oluşturulan/güncellenen/artan veri setlerine sahip bazı internet sitelerinin (iett.istanbul, sahibinden.com, Google Maps, Instagram) verileriyle birlikte İstanbul'un Kadıköy ilçesine ait kent kurgusu için kullanılmıştır.

AKBANK: Türkiye'nin en büyük bankalarından biri olup sigorta acenteliği faaliyetleri de yürütmektedir. Dünyadaki teknolojik eğilimler doğrultusunda altyapısına önemli yatırımlar yapmaktadır (SABANCI, 2021).

$\mathrm{BV}$, iç ve dış veri kaynaklarının sürekli birleştirilmesini, müşteri ve organizasyonu anlamak üzere yapılandırılmış ve yapılandırılmamış verilerin bir araya gelmesini içermektedir. Bu amaçla, BV alt yapısı yeniden düzenlenmiştir. Çözüm ortakları ile yapılan çalışmalarda, farklı veri kaynaklarında depolanmış pazarlama kampanyası verileri ve sonuçları birleştirilerek analizlerin çalıştırılma süresi düşürülmüş ve yeni davranışsal içgörüler arayan kampanya verileri oluşturulmuştur. Böylece, kampanyalar bittikten sonra değil devam ederken sonuçları görmeye olanak veren müşteri merkezli bir sistem oluşturulmuştur (Datameer, 2021).

Akbank, BV'nin hem görsel olarak sunabildiği hem de işlemlerin müşteriye özel gerçekleştirebildiği bir mobil uygulamaya sahiptir. YZ altyapısı ile hazırlanan uygulamada, finansal kararlara yardımcı olacak kişiselleştirilmiş içgörüler ve akıllı ipuçları yer almaktadır (Akbank, 2021). Uygulamada, 300 fonksiyon, 40 farklı içgörü senaryosu, 23 milyon içerik yer almaktadır. Bu içeriklerle, haftalık nakit akışına ilişkin öngörü ve önerilerin yanı sıra kullanıcıların karşılarına çıkan içerikleri kişiselleştirme olanağı sunulmaktadır (İçözü, 2021). Mobil girişin kullanıcının özçekim fotoğrafıyla da yapılabilmesi, yapılandırılmamış verinin kullanımına ilişkin net bir özelliktir.

Kullanıcıların internette arama yaparken, sosyal medya hesaplarını kullanırken ya da mobil uygulamada bıraktıkları dijital izler BV sayesinde bankacılık sistemi tarafından kullanılmakta, kişiye özel hizmet ve ürün teklifleri sunulmaktadır. Örneğin otomobil ya da konut incelemesi yapıldığında, BV krediye ihtiyaç duyulduğunu öngörmekte ve kredi olanakları sunulmaktadır. İhtiyaç kredilerinin \%50'si mobil uygulama üzerinden gerçekleşmektedir (Ekonomist, 2017). Yine sosyal medyanın etkisiyle insanlar, deneyimlerini geliştirmek üzere konum bilgilerini ve alışkanlıklarını paylaşmaktadır. Bu da işletmelerin teknoloji destekli doğru stratejiler geliştirmesi için bir avantaj oluşturmaktadır. Şirket BV'sinin önemli bir kısmını müşterilerin ihtiyaç ve davranışlarını anlamak üzere kullanılan konum verileri oluşturmaktadır. Konum verileri, çok kanallı bir yaklaşım (müşteriler, dağıtım ağları, iş ortakları) ile hizmet ve satış arasındaki çift yönlü verimliliğin artırılmasını sağlamaktadır. Bu amaçla, 40 milyon müşteri adresi, 300.000 üye işyeri, 900 şube ve 4000 ATM'nin coğrafi koordinatları tanımlanmıştır. Bu ana veri kaynaklarına oteller, eczaneler, restoranlar ve diğer perakendeciler ile birlikte 500.000 ilgi çekici nokta eklenmiştir. Böylece konum analizleri için temel veri tabanı oluşturulmuş; uygulamalar, alt yapıyı kullanarak iş firsatları yaratacak şekilde tasarlanmıştır. Bundan elde edilecek faydalar, pazarlama stratejilerini yerelleştirme, konum tabanlı müşteri analizi ve hizmet modellemesi, ATM'lerin hizmet dışı olması durumunda mevcut en yakın ATM konumunu göstermek üzere günlük veri güncellemesi, en yakın şube-ATM-üye işyerlerini SMS ile sorgulama, mobil tabanlı hizmet, potansiyel müşteri kazanma, müşteri portföyünün en uygun şube ve yöneticilere dağıtılması, satış optimizasyonu, en yüksek ürün eğilimi ya da en yüksek kayıp oranına sahip müşterileri belirleme olarak ortaya konmaktadır. Bununla birlikte, sektör düzenlemeleri ve müşteri gizliliği sorunları, bankalar için satış ve pazarlamada jeo-analitik kullanımı hassas 
kılmaktadır. Bunun için izinli pazarlama kuralları, mobil uygulama güvenliği ve gizlilik ayarlarını sağlamak üzere altyapılar tasarlanmaktadır (Bayrak, 2016).

BV'nin gerçek zamanlı kullanıldığı bir başka örnek ise ödemeye dönük bir projenin ürünü olan uygulamadır. Bu uygulama, gençler arasında herhangi bir banka müşterisi olma zorunluluğunu ortadan kaldırarak para çekme, yatırma, transfer gibi günlük finansal işlemleri kolay, hızlı ve eğlenceli biçimde çözmeyi hedeflemektedir. Uygulama, BV'yi hedef kitlenin gündelik alışkanlıklarını temel alarak, sosyal etkileşim yönüyle de farklılaştırmaktadır. Kullanıcılar gerçekleştirdikleri tüm işlemleri arkadaşlarıyla paylaşabilmekte, birbirlerini takip edebilmekte ve paylaşımlarını görebilmektedirler (SABANCI, 2021).

Geleceğe dönük dijital dönüşüm projelerinde; bireysel kredi puanlaması, onay oranlarını artırma, kredi kararı risklerini azaltma üzerine geleneksel olmayan kredi verilerinin analizi yer almaktadır. Böylece, gerçek zamanlı kredi onayı için YZ algoritmalarıyla verimlilik artışı hedeflenmektedir. Ayrıca; finans ve bankacılık işlemleri için algoritmik tabanlı ve değiştirilemez kayıt altyapısı sunan Blok Zincir (Blockchain) teknolojisine dönük çalışmalar başlatılmış, bu teknoloji temelinde para transfer sistemi oluşturulmuştur (Platinonline, 2019).

ENERJISSA: Elektrik dağıtımı ve satışından oluşan iki ana iş kolu bulunan enerji şirketidir. 14 ilde 10.1 milyon müşteriye ulaşarak yaklaşık 21 milyonu aşkın kullanıcıya dăğıtım hizmeti sağlamaktadır (Enerjisa, 2021).

BV ile müşteriyi tanımanın yolu müşterinin veri tabanındaki hareketlerini izlemekle mümkündür. Enerjisa bu konuda müşteri verilerine yönelik tek bir havuz oluşturmak üzere çözüm ortağıyla birlikte kayıtları birleştirip temizlemiş ve bu şekilde çift kopyalar azaltılarak \%25 daha az kayıt elde edilmiştir. Ayrıca elde edilen veriler, ticaret odaları ve merkezi nüfus idaresi gibi dış kuruluşların verileriyle eşleştirilerek zenginleştirilmiş, müşteri bilgilerinin tamlık oranı \%30 artırılmıştır. Böylece, daha güvenli müşteri bilgileriyle daha detaylı bir hizmet ve pazarlama yaklaşımı geliştirebilmek için kritik bir adım atılmıştır (SAS, 2021b).

Şirket; 3 rüzgâr, 2 güneş enerjisi, 3 doğalgaz, 12 hidroelektrik ve 1 yerli linyit santrali ile hizmet vermektedir. $\mathrm{Bu}$ santrallerin bakım ve yapılandırma çalışmaları sırasında incelenmesi gereken dokümanlar, yapılandırılmamış veri niteliği taşıyan plan, proje, liste ve çizimlerden oluşmaktadır. Örneğin yapıların tespiti için kuşbakışı görüntüleri içeren son planların kullanılması gerekmekte ya da bazen aylar ya da yıllar öncesindeki dokümanlara ihtiyaç duyulmakta, bunlara ulaşılamaması durumunda denetim cezaları ile karşılaşılmaktadır. Bu nedenle, dokümanlar üzerindeki kontrol ve ulaş1labilirlik oldukça önem arz etmektedir. BV'nin değer yaratabilmesi için güvenilir verilerle analiz edilmesi gereklidir. Bu doğrultuda aynı dokümanın birkaç farklı örneğini kaydetme, farklı veri tabanında yinelenmesi, yanlış dokümanla çalışma gibi risklerin önlenmesi amaçlarıyla kurumsal içerik yönetim sistemi yeniden düzenlenmiştir. Dijital belgelerin sınıflandırılması için 22 yeni sınıf ve 114 alt sınıf kurulmuştur. Böylece, zenginleştirilmiş elektronik içerikten veri sorgulama ve analizi kolaylaşmış, enerjinin sürekliliği için bakım ve yapılandırma işlemlerinin optimizasyonu sağlanmış, tam denetim raporu doküman yönetimine tutarlılık getirilmiştir. Böylece, denetçilerin bilgi isteklerinin cevaplanması kolaylaşmış, olası ceza riskleri de ortadan kalkmıştır (BBS, 2021).

İşletmenin BV'si çoğunlukla yapılandırılmamış verilerden oluşmaktadır. Bunlardan birisi de Nİ cihazlarından elde edilen verilerdir. Kurumun dağıtımını sağladığ 1 enerjinin \%40'^ bu cihazlar üzerinden okunmakta ve kesinti bilgileri yaklaşık 30 sn içinde sistemlerde görülebilmektedir. Koordinat sistemine göre belirlenmiş aydınlatma tesisatlarının hangi saatte açılıp kapatılacağ1 belirlenebilmektedir. Bu nedenle NI cihazları, BV için veri kaynağı olarak kritik bir noktada yer almakta ve bu cihazların mevcut tesisatların tamamına yaygınlaştırılması için çalışmalar devam etmektedir. Bu cihazlarla, İş Sağlı̆̆ı ve Güvenliği (İSG) çalışması da yapılmaktadır. Bir elektrik şebekesine müdahale öncesinde, ilgili ekip gerçek zamanlı bir video aracılığıyla kontrol merkeziyle 
görüntü paylaşımı yapmakta, onay sonrası şebekeye İSG'ye uygun biçimde müdahale edilmektedir. Bu uygulama mobil Nİ ortamında önemli bir veri transferini göstermektedir (Öğer, 2020).

Firmanın yapılandırılmamış verilerinden bir diğeri de santrallerde görülmektedir. Santrallerin tümünde bulut teknolojileri kullanılarak çözüm üretilmektedir. Bu çalışmalar, enerji üretimi ve ticaretindeki işlemler, vadeli işlemler, gün öncesi ve gün içi piyasalar için optimizasyon uygulamalarını içermektedir. Şirket tarafından sunulan en önemli çözüm, bu üç uygulamanın bağlantılı olarak çalışmasını sağlamaktır. Örneğin, bir Nİ cihazı tüm tesislerden gerçek zamanlı veri toplamaktadır. Bu veriler, bulut sistemleri üzerinde bir uygulamada görüntülenmekte, gün içi piyasa optimizasyonları ve tahminler buna göre yapılmaktadır. Bulutta depolanan ikinci bir uygulama, beklenen çıktı hakkında pazara günlük bilgi vermekte, tesisin üretim kapasitesini planlamakta ve karar verme için gerçekçi rakamlar sunmaktadır. Böylece, daha hızlı kurulum ve geliştirme, müşteri sorgularının hızlı çözümlenmesi, dağıtım sıklığı ve yeniden yükleme süresinin iyileştirilmesi gibi faydalar sağlanmıştır. İşletmede Nİ ile entegrasyonu sağlanan söz konusu bulut veri çözümü; işletmenin sürekli teslimatta avantaj kazanması, test ve dağıtım otomasyonu, sürekli test ve entegrasyon, izleme ve gözlemleme gibi teknik uygulamaları ilerletmesi için de etkili olmuştur (Microsoft, 2021).

Çeşitli uygulamalar ile dijital dönüşümünü gerçekleştiren şirket, sanal gerçeklik uygulamalarıyla da teknolojik etkinliğini artırmıştır. Artırılmış gerçeklik gözlüğü kullanılarak işlerin uzaktan kumanda edilebiliyor oluşu, zorlu yerlerde çalışılabilmesini mümkün hale getirmiştir. Bunun bir uygulaması, doğal gaz tesisinde gerçekleştirilen son bakım çalışmaları ve test aşamalarında gerçekleştirilmiştir. Bir diğer uygulama ise linyit fabrikasında her depoyu kişisel olarak ziyaret eden bir merkez çalışanının yürüttüğü fiziksel stok sayımı sisteminin uzaktan stok sayımı ile değiştirilmesi ve saha çalışması için sanal iş birliği yapılmasıyla olmuştur. Böylece iş süreçlerini iyileştirme ve hızlandırma mümkün olmuştur (Microsoft, 2021). Şirket bu çalışmalarla hem değer elde etmiş hem de veri şirketi olma yönündeki hedefini gerçekleştirmiştir. Gelecek planlarında, BV'nin YZ ile daha etkin değerlendirilmesini sağlayacak projelere yer verilmektedir.

\section{SONUÇ}

Teknolojiye bağlı gelişen akıllı cihazların etkileşimi ve insanların internette gerçekleştirdiği işlemlerin bıraktığı izler verinin farklı türlerde, çok hızlı bir şekilde artmasına sebep olmaktadır. Söz konusu hacim, hız ve çeşitlilik bileşenlerine ek olarak veri, güvenilebilir/doğrulanabilir özellikte değer üretebildiği zaman BV olarak adlandırılmaktadır. BV'nin güvenilir olabilmesi için doğru kaynaklardan alınması ve değer üretebilmesi için analiz edilmesi gerekmektedir. Analizde geleneksel yöntemler yerine YZ ve VM teknikleri kullanılmaktadır. Başarılı iş uygulamaları, teknik altyapı yatırımlarına, alan uzmanlarının yetkinlik düzeyine ve özellikle değer yaratma potansiyelinin keşfedilmesiyle mümkün hale gelmektedir.

BV işletmelere kendilerini değerlendirebilmek ve firsatları yakalayabilmek üzere olanaklar sunmaktadır. $\mathrm{Bu}$ durumun farkında olan işletmeler, BV'yi anlamak, anlamlandırmak, ilişkiler kurabilmek ve buna bağlı olarak ortaya çıkan bilgilerle büyümeyi hedeflemişlerdir. Bu doğrultuda çalışmada, Türkiye'de perakendecilik, e-ticaret, bankacılık, enerji sektörlerinde faaliyet gösteren işletmelerin BV uygulamalarına yer verilmiş ve aşağıdaki sonuçlar elde edilmiştir.

Çalışmada yer alan işletmelerin BV'yi doğru kurgulamak üzere ilk adımları BV'yi analiz için hazırlamak olmuştur. Bunun için iç ve dış veri kaynakları birleştirilmiş, yapılandırılmış ve yapılandırılmamış veriler bir araya getirilmiş, veri indirgeme ya da zenginleştirme yapılarak BV daha sade, güvenilir ve işlenebilir hale getirilmiştir. Böylece; veriler arasındaki ilişkiler, bağlantılar ve örüntüler ortaya çıkartılabilmiş, alınacak kararların sonuçlarını kestirmek mümkün olmuştur. İşletmelerin BV kaynakları; müşteri (kişisel, demografik, ses, fotoğraf, video, beğeni, yorum, 
paylaşım, tercih), ürün (tür, miktar, fiyat, satın alma sıklı̆̆ı, renk, beden), Nİ cihazları, sensörler, web ve mobil uygulama (konum, giriş zamanı ve sayısı, tıklama, görüntüleme, ziyaret), doküman (plan, program, liste, çizim) verilerinden oluşmaktadır. Ayrıca, kendi verileri dışındaki hava durumu, sosyal medya siteleri, arama motoru sorguları, ticaret odaları ve merkezi nüfus idaresi gibi diş kuruluşların verileri de işletmelerin BV'lerinin bir kısmını oluşturmaktadır.

İşletmeler, BV'yi analiz etmede hem kendi teknolojik donanım ve yazılım kaynaklarını kullanmışlar hem de BİT ve iş analitiği işletmeleri ile GSM operatörleri gibi çözüm ortaklarının sunduğu hizmetlerden faydalanmışlardır. Bu doğrultuda elde edilen değerlerin bütün sektörlerde; müşteri temelli kişiselleştirme, müşteri kaybının önlenmesi, yeni müşteri kazanma, müşteri sadakati, ürün ve iş geliştirme, talep tahmini, pazarlama çalışmaları, marka iş birlikleri geliştirme, yatırım kararı alma, satış optimizasyonu, karlılık ve veri görselleştirme konularında olduğu belirlenmiştir. Bunlardan farklı olarak bankacılık sektöründe nakit akışı öngörme; enerji sektöründe üretim ve ticaret işlemlerini izleme ve gözlemleme, vadeli işlemler, gün öncesi ve gün içi piyasalar için optimizasyon, sürekli teslimatta avantaj, sürekli test ve entegrasyon, daha hızlı kurulum ve geliştirme, müşteri sorgularının hızlı çözümlenmesi, dağıtım sıklığı ve yeniden yükleme süresinin iyileştirilmesi gibi faydalar sağlanmıştır. İş modellerinde BV'nin merkezde yer aldığı bu işletmelerin gelecekteki çalışmaları, YZ teknikleriyle güçlendirilmiş giyilebilir teknolojiler, kredi verileri analizi, para transfer sistemi, artırılmış ve sanal gerçeklik uygulamaları ile devam etmektedir.

Sonuçlar; BV'nin ekonomik değer kaynağı olduğunu, içgörüler ya da değer yaratan mal ve hizmetler üretmek için bilgiden faydalanılması gerektiğini, değer elde etmeksizin yapılan analizlerin işletmelere katkı sağlamayacağını, herhangi bir BV planı/stratejisi olmayan/gerçekleştirmekte başarısız olan/geç kalan işletmelerin rekabet etmesinin güçleşeceğini göstermektedir.

BV teknolojinin yanı sıra düşünme, algılama ve araştırma yöntemlerinde de değişimler meydana getirmektedir. Doğru kurgulandığı ve kullanıldığı takdirde, işletmelere önemli faydalar sağlamakta ve iş yapma şekillerini değiştirmektedir. Geleceğin işletmelerinde rekabet üstünlüğunün ancak işletme içinde ve dişında bulunan karmaşık bilginin üretilmesi, tüketilmesi ve yönetilmesi sayesinde mümkün olacağı değerlendirilmektedir. Bu kapsamda bu çalışmanın kurumlar, kuruluşlar, işletmeler ve araştırmacılara yol gösterici olacağı düşünülmektedir. Bundan sonraki çalışmalarda; teknik ayrıntıları içeren BV yönetimi ve analitiği çalışmalarını, disiplinler arası proje uygulamalarını artırmak faydalı olacaktır.

\section{KAYNAKÇA}

Akar, B. (2016, 5 Ocak). "Vaka II: Yemek Sepeti ve Büyük Veri”, Harvard Business Review Türkiye, https://hbrturkiye.com/video/vaka-ii-yemek-sepeti-ve-buyuk-veri, (21.03.2021).

Akbank, (2021). “Akbank Mobil”, https://www.akbank.com/tr-tr/hizmetler/Sayfalar/akbank-mobiluygulamasi.aspx, (28.03.2021).

Akıncı, A. N. (2019). "Büyük Veri Uygulamalarında Kișisel Veri Mahremiyeti”, Sektörler ve Kamu Yatırımları Genel Müdürlüğü Uzmanlık Tezi, T.C. Cumhurbaşkanlığı Strateji ve Bütçe Başkanlığı, Yayın No: 0001.

Aksu, H. (2017). Big Data Bilginin Gücü. Pusula Yayıncılık. İstanbul.

Aktan, E. (2018). “Büyük Veri: Uygulama Alanları, Analitiği ve Güvenlik Boyutu”. Bilgi Yönetimi Dergisi, 1(1), 1-22.

Ali, A., Qadir, J., Rasool, R., Sathiaseelan, A., Zwitter, A. \& Crowcroft, J. (2016). "Big Data for Development: Applications and Techniques". Big Data Analytics, 1(2), 1-24. 
Altunışık, R. (2015). “Büyük Veri: Firsatlar Kaynağı Mı Yoksa Yeni Sorunlar Yumağı Mı?’. Yildiz Social Science Review, 1(1), 45-76.

Ariely, D. (2019). “Big Data”, http://efficiens.nu/dl/Big_Data.pdf, (20.07.2019).

Atalay, M. \& Çelik, E. (2017). "Büyük Veri Analizinde Yapay Zekâ ve Makine Öğrenmesi Uygulamaları”. Mehmet Akif Ersoy Üniversitesi Sosyal Bilimler Enstitüsü Dergisi, 9(22), 155 172.

Austin, C. \& Kusumoto, F. (2016). "The Application of Big Data in Medicine: Current Implications And Future Directions". J Interv Card Electrophysiol, 47, 51-59.

Aytaç, Z. \& Bilge, H. Ş. (2020). “Türkiye'de Kamu ve Özel Kurumların Büyük Veri Alanında Mevcut Durum ve Beklentilerinin Değerlendirilmesi Üzerine Nitel Bir Araştırma", BMIJ, 8(5), 4646-4679.

Ayvaz, S. \& Salman, Y. B. (2020). “Türkiye'de Firmaların Büyük Veri Teknolojileri Bilinirliği ve Kullanımı Analizi”. Avrupa Bilim ve Teknoloji Dergisi, (18), 728-737.

Bbva, Banco Bilbao Vizcaya Argentaria (2020, 26 Mayıs). "The Five V's of Big Data", https://www.bbva.com/en/five-vs-big-data/amp/, (20.12.2020).

Baum, J., Laroque, C., Oeser, B., Skoogh, A. \& Subramaniyan, M. (2018). “Applications of Big Data Analytics and Related Technologies in Maintenance-Literature-Based Research”. Machines, 6(54), 1-12.

Bayrak, A. (2016, 4 Mayıs). "Location Analytics is A Part of Big Data Initiative in Akbank", Geospatial World, https://www.geospatialworld.net/article/location-analytics-is-a-part-of-bigdata-initiative-in-akbank/, (28.03.2021).

Begenau, J., Farboodi, M. \& Veldkamp, L. (2018). "Big Data in Finance and The Growth of Large Firms". Journal of Monetary Economics, 97, 71-87.

Bilgek. (2017, 29 Eylül). "Yemeksepeti İle Kent Tasarlamak", Arkitera Mimarlık Merkezi, https://www.arkitera.com/gorus/yemeksepeti-ile-kent-tasarlamak/, (25.03.2021).

BBS, Bilgi Birikim Sistemleri (2021). "ENERJISA Başarı Hikayesi”, https://www.bilgibirikim .com/Pages/EnerjiSA.aspx, (28.03.2021).

BTK, Bilgi Teknolojileri Ve İletişim Kurumu (2020). "Dünyada ve Ülkemizde Sayısal Dönüşüm: Endüstri 4.0, Yapay Zekâ ve Büyük Veriye İlişkin Gelişmeler”, Sektörel Araştırma ve Strateji Geliştirme Dairesi, Sayısal Dönüşüm Raporu, Ankara, https://www.btk.gov.tr/ uploads/pages/arastirma-raporlari/sayisal-donusum-rapor.pdf, (04.04.2021).

Birinci, Ş. (2015). "Sağl1kta Büyük Veri”, https://www.acibadem.edu.tr/doc/SuayipBirinci_ SagliktaBuyukVeri.pdf, (04.04.2021).

Boyner, C. (2017). Boyner Büyük Veri. (Ed.), Güvenir, H. A, İş Hayatında Büyük Veri Konferans Raporu içinde (53-62), TÜSİAD-T/2017, İstanbul.

Cao, S. \& Manra1, A. K. (2014). "Big Data in Marketing \& Retailing”. Journal of International \& Interdisciplinary, Business Research, 1(1), 23-42.

Cousins, S. (2018). "Big City Big Data", https://www.rics.org/fr/wbef/megatrends/digitaltransformation/big-city-big-data/, (23.12.2020).

Çark, Ö., Yıldız, İ. \& Karadeniz, A. T. (2019). “Sanayi 4.0 Kapsamında İşletmeler Açısından Büyük Veri". International Journal of Multidisciplinary Studies and Innovative Technologies, 3(2), 114-120. 
Çelik, S. (2018). Büyük Veri. Gece Akademi. Aydın.

Çiğdem, Ş. \& Seyrek, İ. H. (2015). İşletmelerde Büyük Veri Uygulamaları: Bir Literatür Taramasi. 2.Ulusal Yönetim Bilişim Sistemleri Kongresi, Erzurum, Türkiye.

Datameer (2021). "Akbank Accelerates Marketing With Agile Analytics", https://www.datameer .com/akbank-case-study/, (23.03.2021).

Davenport, T. H. \& Dyché, J. (2013). "Big Data in Big Companies", International Institute for Analytics, https://www.iqpc.com/media/7863/11710.pdf, 25.02.2020.

Demirezen, M. U. (2017). Büyük Veri ve Büyük Veri İşleme Mimarileri. (Ed.), SAĞIROĞLU, Ş ve KOÇ, O., Büyük Veri ve Açik Veri Analitiği: Yöntemler ve Uygulamalar içinde (131-165), Grafiker Yayınları, Ankara.

Demirtaş, B. \& Argan, M. (2015). "Büyük Veri ve Pazarlamadaki Dönüşüm: Kuramsal Bir Yaklaşım”. Pazarlama ve Pazarlama Araştırmaları Dergisi, 15, 1-21.

Doğan, K. \& Arslantekin, S. (2016). “Büyük Veri: Önemi, Yapısı ve Günümüzdeki Durum”. DTCF Dergisi, 56(1), 15-36.

Edosio, U. (2014). "Big Data Analytics And Its Application in E-Commerce Using Case Studies of Adidas, Walmart and Amazon.com", https://www.researchgate.net/publication/264129339 _Big_Data_Analytics_and_its_Application_in_E-Commerce/link/53cf8ef30cf2f7e 53cf811e0/ download, (09.06.2020).

Ekonomist (2017). “Dijital İzleri Takip Ediyoruz", https://www.ekonomist.com.tr/finans/dijitalizleri-takip-ediyoruz.html/amp, (28.03.2021).

Enerjisa (2021). https://www.enerjisa.com.tr/tr/enerjisa-hakkinda/sirket-profili, (07.04.2021).

Eravcı, D. B. (2020). “Kurumların Dijital Dönüşümü: Büyük Veri”, Çalışma İlişkiler Dergisi, 11(1), 90-112.

Erevelles, S., Fukawa, N. \& Swayne, L. (2016). "Big Data Consumer Analytics and The Transformation of Marketing". Journal of Business Research, 69, 897-904.

Ergen, Y. (2018). "Büyük Veri, Sosyal Medya ve Etik: Facebook Örneğinde Bir Değerlendirme". Yeni Düşünceler, 10, 53-64.

Ersöz, F. (2019). Dijitalleşme Çağında Büyük Veri ve Analitiği: Sektörel Uygulamalar. 4th International Congress on 3d Printing (Additive Manufacturing) Technologies and Digital Industry, 11-14 Nisan 2019, Antalya, 712-720.

Fayyad, U. (2017). Big Data. (Ed.), Güvenir, H. A., İş Hayatında Büyük Veri Konferans Raporu içinde (19-52), TÜSİAD-T/2017, İstanbul.

Forsdick, S. (2019). "Big Data in Transport: How TfL is Tracking and Improving Journeys With Tech”, https://www.ns-businesshub.com/technology/big-data-in-transport-tfl/, (23.07.2019).

Gobble, M. A. M. (2013). "Big Data: The Next Big Thing in Innovation”. Research-Technology Management, 56(1), 64-67.

Guru99 (2019). "What is Big Data? Introduction, Types, Characteristics, Example", https://www. guru99.com/what-is-big-data.html, (27.06.2019).

Gürsakal, N. (2017). Büyük Veri. Dora Yayıncılık. Bursa.

Hadi, H. J., Ammar, H. S., Hadishaheed, S. \& Ahmad, A. H. (2015). "Big Data and Five V's Characteristics". International Journal of Advances in Electronics and Computer Science, 2(1), 16-23. 
Hadoop (2021). "Sources of Big Data", http://www.hadoopadmin.co.in/sources-of-bigdata/, (19.03.2021).

Hurwitz, J., Nugent, A., Halper, F. \& Kaufman, M. (2013). Big Data For Dummies. John Wiley ve Sons Inc. New Jersey.

IBM, International Business Machines (2021). "Büyük Veri Analitiği Nedir?”, https://www.ibm.com/tr-tr/analytics/hadoop/big-data-analytics, (19.03.2021).

Iyzico (2021). “Iyzico 2020 Online Alışveriş Raporu”, https://www.iyzico.com/blog/iyzico-2020online-alisveris-raporu/, (30.03.2021).

İçözü, T (2021, 22 Şubat). "Akbank Mobil'in Kullanım Verileri ve Akbank'ın Uzaktan Müşteri Edinimine Dair Detaylar", https://webrazzi.com/2021/02/22/akbank-mobil-in-kullanimverileri-ve-akbank-in-uzaktan-musteri-edinimi-detaylari/, (28.03.2021).

Jacqueleen, A. R. (2015). "The Skinny on Big Data in Education: Learning Analytics Simplified". TechTrends, 59(2), 75-80.

Kamilaris, A., Kartakoullis, A. \& Prenafeta-Boldú, F. X. (2017). "A Review on The Practice of Big Data Analysis in Agriculture". Computers and Electronics in Agriculture, 43, 23-37.

Keeso, A. (2014). "Big Data and Environmental Sustainability: A Conversation Starter", Smith School of Enterprise and The Environment \& University of Oxford, 14-04, https://www. smithschool.ox.ac.uk/publications/wpapers/workingpaper/14-04.pdf, (23.07.2019).

Klein, M. (2020). “Iş̧letmelerde Dijital Dönüşüm ve Etmenleri”. Journal of Business in The Digital Age, 3(1), 24-35.

Koltan Yilmaz, Ş. (2019). Big Data and Big Data Applications in The World. 5th International Regional Development Conference, Malatya, Türkiye, 26-28 Eylül 2019, 867-884.

Köseoğlu, Ö. \& Demirci, Y. (2017). “Türkiye'de Büyük Veri ve Veri Madenciliğine İlişkin Politika ve Stratejiler: Ulusal Politika Belgelerinin İçerik Analizi”. Süleyman Demirel Üniversitesi İktisadi ve İdari Bilimler Fakültesi Dergisi, Kayfor15 Özel Sayıs1, 22, 2223-2239.

Lewis, L. (2020, 10 Mart). "Infographic: What Happens In An Internet Minute 2020", https://www.allaccess.com/merge/archive/31294/infographic-what-happens-in-an-internetminute, (21.12.2020).

Ma, C., Smith, H. W., Chu, C. \& Juarez, D. T. (2015). "Big Data in Pharmacy Practice: Current Use, Challenges, and The Future". Integrated Pharmacy Research \& Practice, 4, 91-99.

Majumdar, J., Naraseeyappa, S. \& Ankalaki, S. (2017). “Analysis of Agriculture Data Using Data Mining Techniques: Application of Big Data". J Big Data, 4(20), 1-15.

Marr, B. (2019). Büyük Veri İş Başında, (Çev.) Gündüz B., MediaCat Kitapları, İstanbul.

Massie, A. B., Kuricka, L. M. \& Segev, D. L. (2014). "Big Data in Organ Transplantation: Registries and Administrative Claims", American Journal of Transplantation, 14, 1723-1730.

Mayer-Schönberger, V. \& Cukier, K. (2013). Büyük Veri, (Çev.) EROL, B., Paloma Yayınevi, İstanbul.

Memon, M. A., Soomro, S., Jumani, A. K. \& Kartio, M.A. (2017). "Big Data Analytics and Its Applications". Annals of Emerging Technologies in Computing (AETiC), 1(1), 45-54.

Microsoft, (2021). "ENERJISA Üretim Speeds Up Innovation Through Azure Structured Cloud Architecture", https://customers.microsoft.com/en-us/story/1336488647485179816-enerjisauretim-energy-azure-en-turkey, (23.03.2021). 
Mishra, R. \& Sharma, R. (2015). “Big Data: Opportunities and Challenges”. International Journal of Computer Science \& Mobile Computing, 4(6), 27-35.

Mukherjee, S. \& Shaw, R. (2016). "Big Data-Concepts, Applications, Challenges and Future Scope". International Journal of Advanced Research in Computer and Communication Engineering, 5(2), 66-74.

Onay, A. (2020). “Büyük Veri Çağında İç Denetimin Dönüşümü”. Muhasebe Bilim Dünyası Dergisi, 22(1), 127-163.

Öğer, G. (2020, 27 Şubat). “Turkcell'in Veri Merkezi Yatırımları Sektörümüz Adına Bizi Çok Heyecanlandırd1!", İşte Teknoloji, https://www.isteteknoloji.com.tr/uncategorized/2020/02/27/ turkcellin-veri-merkezi-yatirimlari-sektorumuz-adina-bizi-cok-heyecanlandirdi/, (23.03.2021).

Özdoğan, O. (2016). Büyük Veri Denizi. Elma Yayınevi. Ankara.

Pehlivan, A. S. (2019, 8 Ağustos). “Akıllı Alışverişe Odaklanacak”, https://www.ekonomist.com. tr/soylesi/akilli-alisverise-odaklanacak.html/amp, (23.03.2021).

Platinonline, (2019). “Akbank Akı1lı Dijital Geleceği Tasarlıyor”, https://www.platinonline. com/dijital-trend/akbank-akilli-dijital-gelecegi-tasarliyor-999956, (28.03.2021).

Reinsel, D., Gantz, J. \& Rydning, J. (2018). "The Digitization of The World - From Edge To Core", An IDC White Paper, https://www.seagate.com/files/www-content/our-story/trends/ files/idcseagate-dataage-whitepaper.pdf, (21.12.2020).

Sabanc1, Sabanc1 Topluluğu (2021). https://www.sabanci.com/tr/sabanci-toplulugu/ akbank, (28.03.2021).

Sabanc1 Üniversitesi (2021). "SAS Becomes The Analytical Partner of Turkey's First Big Data Lab", https://sbs.sabanciuniv.edu/en/sas-becomes-analytical-partner-turkeys-first-big-data-lab, (28.03.2021).

Sağıroğlu, Ș. (2017). Büyük Veri Dünyası: Büyük Veri Büyük Etki. (Ed.), SAĞIROĞLU, Ş ve KOÇ, O., Büyük Veri ve Açık Veri Analitiği: Yöntemler ve Uygulamalar içinde (81-97), Grafiker Yayınları, Ankara.

Sağıroğlu, Ş. (2019). Büyük ve Açık Veri Türkiye Uygulamaları. Büyük Veri Uygulamaları Konferans1, BTK Konferans Salonu, 26 Haziran 2019, Ankara. http://bigdatacenter.gazi.edu.tr/ wp-content/uploads/BTK_BuyukVeriTurkiye2019.pdf, (19.03.2021).

Salvador, A. B. \& Ikeda, A. A. (2014). "Big Data Usage in The Marketing Information System". Journal of Data Analysis and Information Processing, 2, 77-85.

Sanchez, F. M. \& Verspoor, K. (2014). "Big Data in Medicine is Driving Big Changes”. Yearb Med Inform, 9(1), 14-20.

SAS, Statistical Analysis Software (2021a). "Boyner Grup Müşterisi Vizyonuyla 360 Derece Müşteri Görünümü”, https://www.sas.com/tr_tr/customers/boyner.html, (23.03.2021).

SAS, Statistical Analysis Software (2021b). "Enerji lideri veriyi müşteri bilgisine dönüştürüyor", https://www.sas.com/tr_tr/customers/enerjisa-02.html, (23.03.2021).

Satı, Z. E. (2015). Tedarik Zinciri Yeterliliklerini Artirmada İnovasyon ve Büyük Veri (Big Data) nin Etkileşimini Değerlendirme. Uluslararası Katılımlı 15. Üretim Araştırmaları Sempozyumu, İzmir, 603-615.

Schulte, D. (2018). “10 Best Big Data Companies 2018”, CIO Bulletin, http://www.ciobulletin. com/magazine/were-using-data-to-make-healthcare-better-apixio, (23.07.2019). 
Scola, N. (2013, 14 Haziran). "Obama, The 'Big Data' President”, https://www.washingtonpost. com/opinions/obama-the-big-data-president/2013/06/14/1d71fe2e-d391-11e2-b05f-3ea3f0e7b b5a_story.html?noredirect=on\&utm_term $=4 \mathrm{dbf5e} 3 \mathrm{a} 7406,(24.07 .2019)$.

Sin, K. \& Muthu, L. (2015). "Application of Big Data in Education Data Mining and Learning Analytics - A Literature Review". ICTACT Journal on Soft Computing: Special Issue on Soft Computing Models for Big Data, 5(4), 1035-1049.

Sravanthi, K. \& Reddyy, T. S. (2015). "Applications of Big Data in Various Fields". (IJCSIT) International Journal of Computer Science and Information Technologies, 6(5), 4629-4632.

Stokes, L. B., Rogers, J.W., Hertig, J.B. \& Weber, R.J. (2016). "Big Data: Implications for Health System Pharmacy". Hospital Pharmacy, 51(7), 599-603.

Su, X. (2019). “Introduction To Big Data”, https://www.ntnu.no/iie/fag/big/lessons/lesson2.pdf, (19.07.2019).

Subrahmanyam, A. (2019). "Big Data in Finance: Evidence and Challenges". Borsa Istanbul Review, 19(4), 283-287.

Şener, E. (2020, 11 Ekim). “Internette 1 Dakikada Neler Oluyor?”, https://www.hurriyet.com.tr/ yazarlar/ergi-sener/internette-1-dakikada-neler-oluyor-41632758, (28.01.2021).

Terzi, R., Sağıroğlu, Ş. \& Demirezen M. U. (2017). Büyük Veri ve Açık Veri: Temel Kavramlar. (Ed.), SAĞIROĞLU, Ş ve KOÇ, O. Büyük Veri ve Açık Veri Analitiği: Yöntemler ve Uygulamalar içinde (13-30), Grafiker Yayınları, Ankara.

Thebrandage (2021). "Boyner.com.tr Akıllı Hava Durumu Uygulamasıyla Müşteri İlgisi ve Satışlarını Artırdı", https://www.thebrandage.com/boynercomtr-akilli-hava-durumuuygulamasiyla -musteri-ilgisi-ve-satislarini-artirdi, (23.03.2021).

Thulara, N., Hewage, M. N., Halgamuge, A. S. \& Ekici, G. (2018). "Review: Big Data Techniques of Google, Amazon, Facebook and Twitter". Journal of Communications, 13(2), 94-100.

Tomar, L., Guicheney, W., Kyarisiima, H. \& Zimani, T. (2016). Big Data in The Public Sector, InterAmerican Development Bank, Discussion paper, IDB-DP-483.

West, D.M. (2012), "Big Data For Education: Data Mining, Data Analytics, And Web Dashboards", Governance studies, The Brookings Institution, Massachusetts, Washington, http://www.insidepolitics.org/brookingsreports/education\%20big\%20data.pdf, (17.03.2021).

Yemeksepeti (2020). "2020 Lezzet Rehberi”, https://www.instagram.com/p/CJYHOEep9nz/, (26.03.2021).

Yemeksepetiblog (2021). https://blog.yemeksepeti.com/, (25.03.2021).

Yemeksepetiblog (2018, 4 Ocak). “Türkiye'nin 2017 Menüsü Belli Oldu!”, https://blog. yemeksepeti.com/index.php/2018/01/04/turkiyenin-2017-menusu-belli-oldu/, (25.03.2021).

Yemeksepetiblog (2016b, 30 Mart). "Beyaz Yakalılar Her Bahar Aynı Hayali Kuruyor", https://blog.yemeksepeti.com/index.php/2016/03/30/beyaz-yakalilar-bahar-ayni-hayalikuruyor/, (25.03.2021).

Yemeksepetiblog (2016a, 4 Ocak). "Malzemesinden, Promosyonuna Yemeksepeti En Çok Tercih Edilen Pizzayı Açıklıyor!”, https://blog.yemeksepeti.com/index.php/2016/01/04/ yemeksepetien-cok-tercih-edilen-pizzayi-acikliyor/, (25.03.2021). 